\title{
Locally Advanced Unresectable Cervical Adenocarcinoma
}

National Cancer Institute

\section{Source}

National Cancer Institute. Locally Advanced Unresectable Cervical Adenocarcinoma. NCI

Thesaurus. Code C156299.

A cervical adenocarcinoma that has spread from its original site of growth to nearby tissues or lymph nodes and is not amenable to surgical resection. 